\title{
SLAUGYTOJU巳 DARBO PATIRTIES IR INTRAVENINIŲ INJEKCIJŲ KOMPLIKACIJŲ SĄSAJOS
}

\author{
Daiva Narviliené $\dot{1}^{1}$ Jurgita Vaitiekiené ${ }^{2}$, Lidija Visockyte் ${ }^{1}$ \\ ${ }^{1}$ Klaipédos valstybine kolegija, ${ }^{2}$ Klaipédos universitetine ligoniné
}

Raktažodžiai: intraveninès injekcijos, injekcijų komplikacijos, slaugytojų darbo patirtis.

\begin{abstract}
Santrauka
Tyrimo tikslas - išanalizuoti slaugytojų darbo patirties ir intraveninių injekcijų komplikacijų sąsajas. Vykdyta anoniminė apklausa raštu. Tyrimo metu apklausti 185 slaugytojai, dirbantys ịvairaus profilio sveikatos priežiūros istaigose. Duomenys apdoroti IBM SSPS 23.0 statistikos programų paketu. Atlikta kiekybinių kintamujjų dažnių ir vidurkių analizè. Apskaičiuotas tyrimo duomenų dažnis (n), jo procentinè išraiška (proc.), vidurkis ir standartinis nuokrypis. Dviejų nepriklausomų kintamujų palyginimams buvo naudojamas Mann-Whitney testas. Ryšiams nustatyti buvo naudojamas Spearman koreliacijos koeficientas (r) ir jo reikšmingumas (p). Statistinis hipotezių reikšmingumas patvirtintas, kai $\mathrm{p} \leq 0,05$. Tyrimo metu nustatyta, kad slaugytojams, turintiems daugiau nei 10 metų darbo patirties, atliekant intravenines injekcijas, komplikacijų pasitaiko rečiau, nei mažiau patirties turintiems slaugytojams. Tyrimo rezultatai parodè, kad slaugytojai, dirbantys vienoje srityje ne mažiau kaip 20 metų, naudoja intuiciją ir analitinị bei kritinị sprendimų prièmimo būdą. Slaugytojams, kurių darbo patirtis iki penkerių metų, sudètingiau atlikti intravenines injekcijas kritinèse situacijose, vertinti paciento būklę ir galimas intraveninių injekcijų komplikacijas. Šio tyrimo rezultatai padejjo nustatyti intraveninių injekcijų komplikacijų ryši su slaugytoju darbo patirtimi, kad būtu galima išvengti komplikacijų ar sumažinti jų skaičių. Patirties veiksnys parodo kokybini pradedančio ir patyrusio slaugytojo skirtumą, todèl ị profesinę patirtị turi būti atsižvelgiama sprendimų prièmimo procese.
\end{abstract}

\section{Ivadas}

Intraveninès injekcijos vis dažniau atliekamos naudojant periferinius venų kateterius. Didejjant intraveninių kateterių naudojimui, dideja pagrindinių komplikacijų, tokių kaip kateterio kolonizavimas bei intraveninè infekcija, rizika. Šios komplikacijos didina pacientų sergamumą, ilgèja jų gydymosi stacionare laikas, didejja kritinès būklès pacientų mirtingumas [7]. Vienas svarbiausių veiksnių, lemiančių intraveninių injekcijų komplikacijas, yra slaugytojų darbo patirtis, kuri turi įtakos intraveninių injekcijų atlikimui, komplikacijų atsiradimui bei punktuotos kateterio vietos priežiūrai. Ilgametė slaugytojų darbo patirtis bei kompetencija užtikrina kokybiškesnę pacientų slaugą, intraveninių injekcijų atlikimą bei tolimesnį pacientų slaugymą. Didejant intraveninių injekcijų skaičiui ir dèl netinkamo intraveninių kateterių ịvedimo bei priežiūros dažnėja infekcijų, didèja sergamumas, mirtingumas, ilgèja gydymo trukmè, didejja gydymo išlaidos $[3,6]$. Išanalizavus rizikos veiksnius, bei jų sąsajas su slaugytojų darbo patirtimi, būtų galima išvengti komplikacijų ar sumažinti jų riziką [5].

Atliktų tyrimų metu paaiškejjo, jog slaugytojai, turintys didesnę darbo patirtį nei 10 metų, atliko procedūras beveik dvigubai operatyviau, nei slaugytojai, turintys keleriu metu darbo patirtic. Slaugytojai, turintys daugiau nei 20 metų darbo patirties, kritiškiau vertino paciento būklę ir nustate paciento slaugos problemas [2]. Praktikoje noredami ịvertinti paciento būklę, patyrę slaugytojai, skirtingai nei pradedantieji, rinkosi išsamų gyvybinių veiklų vertinimą ir išsirinko tikslingiausius parametrus, būtiniausius numatytoje kritineje situacijoje. Šis skirtumas buvo nustatytas daugelyje atliktų tyrimų $[5,6]$. Tyrejai pažymi, kad pradedantieji slaugytojai, kol igyja darbo patirties, vadovaujasi visomis metodinèmis taisyklèmis, kurios varžo jų veiksmus, nes vieną pasirinktą veiksmų šabloną bando pritaikyti skirtingomis situacijomis. Nors šablonas paremtas standartais, tačiau slaugytojai, turintys praktinès patirties nurodo, jog reikia atsižvelgti i paciento atveji ir prisitaikyti individualiai. Tyrimų rezultatai parodè, kad infiltracijos ir flebito komplikacijų rizika tiesiogiai priklauso nuo slaugytojo žinių bei praktinès patirties. Tyrimo duomenimis, pradedantiesiems slaugytojams intraveninių injekcijų komplikacijų buvo 50 proc. daugiau, nei patyrusiems. Slaugytojų, turinčių didesnę nei 10 metų patirtį, intraveninių kateterių 
ivvedimo laikas trumpesnis, nei pradedančiujų slaugytojų, kuris turi itakos didesnei infiltracijos ir flebito tikimybei [2]. Pastebima, jog intravenines injekcijas sunkino neadekvatus, nenuspejamas pacientų elgesys, kuris injekcijos metu kelia pavojų ne tik pacientui, bet ir injekciją atliekančiam slaugytojui. Dél to pailgeja invazijos laikas, kuris ekstrinèse situacijose labai svarbus, didejja intraveninių komplikacijų tikimybė [8]. Išoriniai veiksniai: prehospitalinès aplinkos neapibrěžtumas, lūkesčiai ir aplinkos spaudimas, bendradarbiavimas su daugeliu skirtingų komandų, sunkina sprendimų prièmimą ekstremaliose situacijose. Tyrimo duomenimis, pradedantieji slaugytojai nurodè pagrindinę priemonę, lengvinančią sprendimų prièmimą, atliekant procedūras, - tai bendradarbiavimas su kolegomis, turinčiais didesnę darbo patirti [7]. Slaugytojai, dirbantys vienoje srityje ne mažiau kaip 20 metų, naudoja intuiciją ir analitinį sprendimų prièmimo būdą. Labai patyrusių slaugytojų grupeje buvo nustatytas intuityvus ir analitinis sprendimų prièmimo komponentų naudojimas, kuris labai efektyvus. Atliktų tyrimų rezultatai aptariami ir pateikiami atsižvelgiant ị dabartinị slaugos praktikos ekspertų sprendimų komponentų supratimą. Tiek intuityvus, tiek analitinis elementai turètų būti pripažįstami kaip modeliai, kuriais siekiama parodyti tikrajį slaugytojų sprendimų prièmimo pobūdị, nes jie sukuria klinikinę patirtị [11].

Tyrimo tikslas - išanalizuoti slaugytojų darbo patirties ir intraveninių injekcijų komplikacijų sąsajas.

\section{Tyrimo medžiaga ir metodai}

Tyrime dalyvavo ịvairaus profilio slaugytojai, dirbantys sveikatos priežiūros įstaigose (ligoninèse, slaugos namuose, greitosios medicinos pagalbos stotyse, pirminès sveikatos priežiūros centruose). Tyrimas vyko 2018 ir 2019 metais. Remiantis užsienio atliktais tyrimais, autorių sudarytas klausimynas, taikyta anoniminė apklausa raštu. Klausimyną sudarè trys struktūrinès dalys: slaugytojų darbo vieta, krūvis, patirtis ir atliekamų injekcijų kiekis; intraveninių injekcijų rizikos

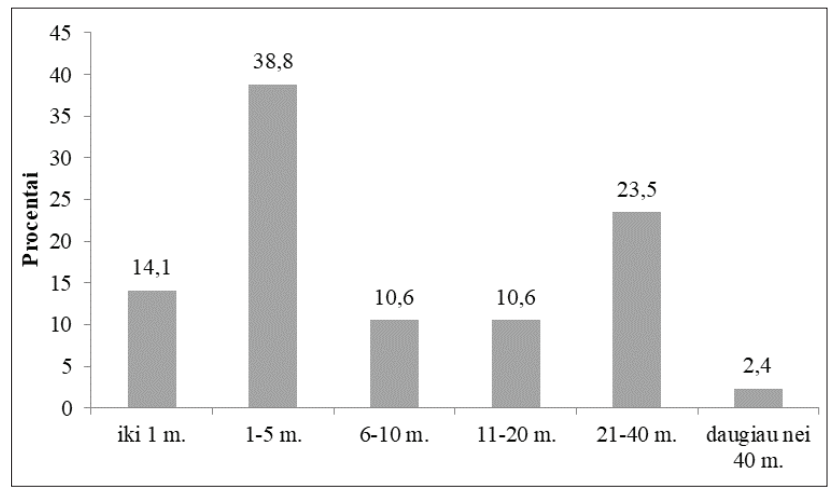

1 pav. Slaugytojų darbo patirties pasiskirstymas, procentais veiksniai, komplikacijos bei jų dažnis ir demografiniai duomenys. Tyrime dalyvavo 185 slaugytojai. Klausimynas buvo ịteiktas voke slaugytojams asmeniškai ir grąžintas užpildytas bei užklijuotas, užtikrinant informacijos konfidencialumą. Duomenų analizei naudotas IBM SSPS 23.0 statistikos programų paketas. Buvo atlikta kiekybinių kintamujų dažnių ir vidurkių analizè. Apskaičiuotas tyrimo duomenų dažnis (n), jo procentinè išraiška (proc.), vidurkis ir standartinis nuokrypis. Dviejų nepriklausomų kintamujų palyginimui buvo naudojamas Mann - Whitney testas. Ryšiams nustatyti buvo naudojamas Spearman koreliacijos koeficientas (r) ir jo reikšmingumas (p). Statistinis hipotezių reikšmingumas patvirtintas, kai $\mathrm{p} \leq 0,05$. Nustatant klausimyno struktūrinių dalių, intraveninių injekcijų rizikos veiksnių ir komplikacijų dažnumo klausimų grupių skalių patikimumą, buvo apskaičiuoti Cronbach alfa koeficientai (nuo 0,752 iki 0,851), parodę labai gerą skalių patikimumą.

\section{Tyrimo rezultatai ir jų aptarimas}

Tyrimo metu apklausti 185 slaugytojai, iš jų 90,6 proc. sudare moterys ir 6,4 proc.- vyrai. Dauguma tyrime dalyvavusių slaugytojų (75,3 proc.) buvo ịgiję aukštaji išsilavinimą, amžius nuo 22 iki 60 metų. Profesinio darbo patirtis: iki 1 metų 14,1 proc.; $1-5$ metai 38,8 proc.; 6-10 ir 11-20 metų 10,6 proc.; 21-40 metų 23,5 proc.; daugiau nei 40 metų darbo patirties turejjo 2,4 proc. tiriamujuc (1 pav.). Atliktų tyrimų rezultatai atskleidè, kad slaugytojai, dirbantys vienoje srityje ne mažiau kaip 20 metų, tampa slaugos praktikos ekspertais, kurdami klinikinę patirti [7].

Analizuota, kiek slaugytojai vidutiniškai per pamainą

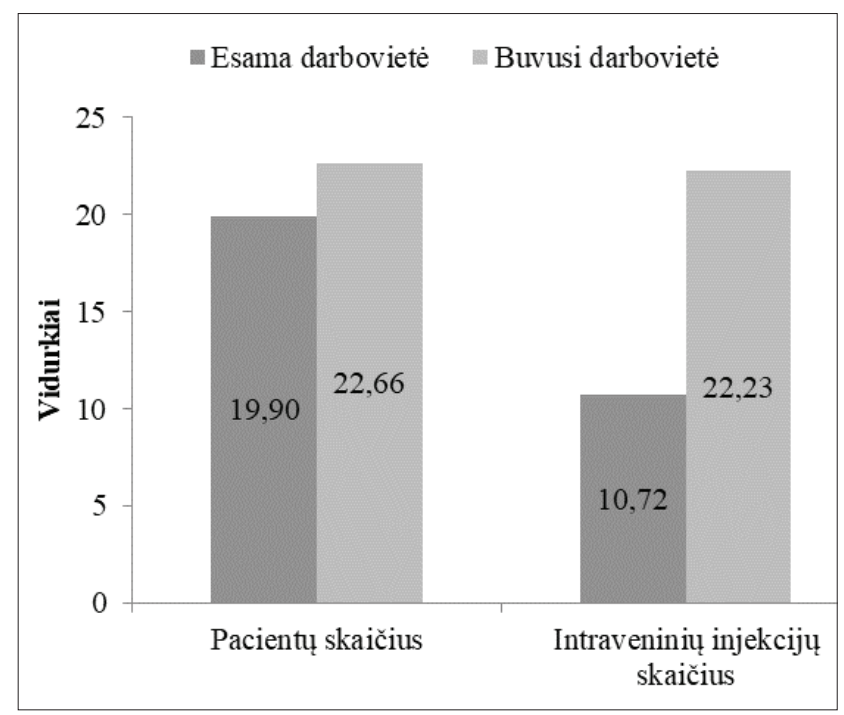

2 pav. Pacientų ir intraveninių injekcijų skaičiaus vidurkiai vienam slaugytojui per pamainą 
slaugo pacientų ir atlieka intraveninių injekcijų ( 2 pav.). Tyrimo duomenimis, esamoje darbovieteje vienam slaugytojui vidutiniškai tenka $19,9 \pm 22,45$ paciento, vidutinis atliekamų intraveninių injekcijų skaičius 10,72 $\pm 17,92$. Ankstesnèse darbovietèse tiriamiesiems vidutiniškai per pamainą teko $22,66 \pm 34,16$ paciento, vidutinis atliekamų intraveninių injekcijų skaičius buvo $22,23 \pm 26,04$.

Slaugytojų darbo krūvio analizès rezultatai parodè, kad dauguma slaugytoju (63,8 proc.) turi 1 etatą, 25,9 proc. $-1,25$ etato, 6,9 proc. $-1,5$ etato ir 3,4 proc. $-0,5$ etato. Slaugytojai nurodè ir buvusị darbo krūvị ankstesnèse darbovietèse (3 pav.).

Tyrimo metu paaiškejjo, kad 22,5 proc. slaugytojų buvo igiję anestezijos ir intensyviosios slaugos specializaciją; 14,6 proc. - bendruomenès slaugos, 7,9 proc. - skubiosios medicinos pagalbos; 4,5 proc. - operacinès slaugos ir 3,4 proc. - psichikos sveikatos slaugos specializaciją. 47,2 proc. tyrime dalyvavusių slaugytojų nurodè, kad nèra ịgiję jokios specializacijos (4 pav.). Dauguma tyrime dalyvavusių slaugytojų ( 64,5 proc.) dirba ligoninèje, 12,8 proc. - pirminès

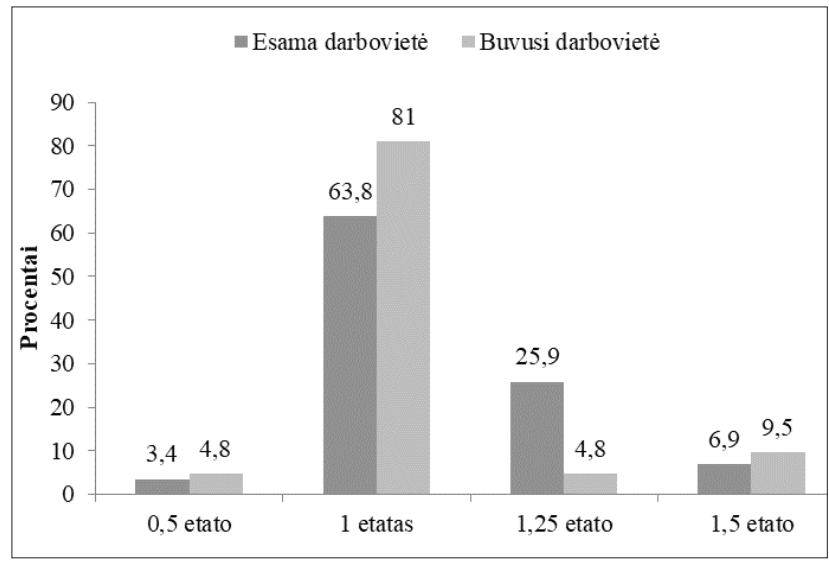

3 pav. Slaugytojų darbo krūvio pasiskirstymas, procentais

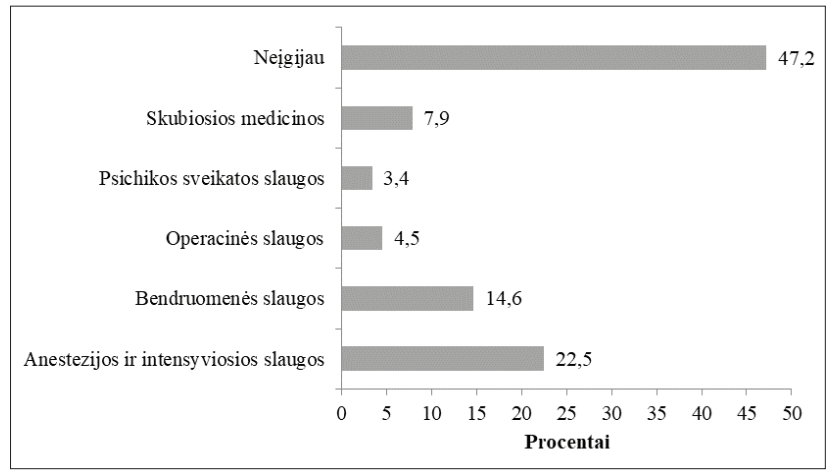

4 pav. Slaugytojų pasiskirstymas pagal ịgytas specializacijas, procentais sveikatos priežiūros centruose, 15,5 proc. - Greitosios medicinos pagalbos stotyje, 7,2 proc. - slaugos namuose.

Tyrimo metu analizuoti intraveninių injekcijų rizikos veiksniai. Dauguma slaugytojų sutiko su teiginiais, kad intraveninio kateterio būklès stebejjimas turi įtakos intraveniniu komplikacijų rizikai $(1,39 \pm 0,62)$, slaugytojo rankų higienos kontrole turi ịtakos intraveninių komplikacijų rizikai $(1,47 \pm 0,84)$, punkcijos vietos tinkamas aseptinis paruošimas turi įtakos intraveninių injekcijų komplikacijų rizikai $(1,53 \pm 0,73)$, retas lašinimo sistemų ilginimo linijų, kranelių keitimas didina komplikacijų tikimybę $(1,58 \pm 0,73)$, o neadekvatus pacientų elgesys sunkina venų punkciją $(1,64 \pm 0,75)$. Lyginant su kitų tyrèjų atliktais tyrimais [2], kurie taip pat nurodo, kad infuzinès sistemos infekuojasi per tris paras net 50 proc. dažniau, todèl jas reikètų keisti kas 48-72 val. Jei nèra kraujo transfuzijų, riebalų emulsijų infuzijų, pakanka keisti kas 72 val. Atliktame tyrime nebuvo analizuojamas slaugytojų darbo patirties bei kitų reikšmingų rodiklių statistinis reikšmingumas (1 lentelè). Atlikto tyrimo rezultatai sutampa su kitų mokslininkų atliktų tyrimų rezultatais. Tyrime dalyvavusieji slaugytojai nesutiko su teiginiais, kad venų pradūrimas dažnesnis naktị, nei dieną $(3,47 \pm 0,93)$; venų pradūrimas dažnesnis dieną, nei naktị $(3,25 \pm 1,01)$; periferinio venos kateterio laikymas ilgiau nei 24 val. didina komplikacijų tikimybę $(3,15 \pm 1,13)$; intraveninès injekcijos vieta parenkama vadovaujantis nuojauta $(3,12 \pm 1,22)$; intraveninių komplikacijų rizika nepriklauso nuo paciento informavimo $(2,91 \pm 1,09)$. Slaugytojai nei sutinka, nei nesutinka, kad parentenine mityba ir darbo krūvis turi įtakos intraveninių komplikacijų rizikai. Panašūs rezultatai gauti ir kitų tyrèjų [1] atliktuose tyrimuose, kuriuose nurodoma, jog dèl parenteninès mitybos ịvyksta intraveninès komplikacijos, tačiau pabrèžiama, kad pagrindinė priežastis - netinkamas aseptikos laikymasis procedūros metu. Dauguma slaugytojų sutinka, jog tai turi itakos intraveninèms komplikacijoms, nes taip perduodami infekcijų sukèlejai.

Tyrimo metu siekiant nustatyti slaugytojų darbo patirties ir intraveninių komplikacijų rizikos veiksniu sąsajas, atlikta koreliacinè (Spearman) analizè (1 lentelè). Tyrimo rezultatu duomenys parodė slaugytojų darbo patirties statistiškai reikšmingus teigiamus ryšius su teiginiu, kad paciento punkcijos vietos tinkamas aseptinis paruošimas turi įtakos intraveninių injekcijų komplikacijų rizikai ( $\mathrm{r}=0.217$; $\mathrm{p}=0.047)$. Lyginant šio tyrimo rezultatus su kitų tyrèjų [1] rezultatais, pastebimas ryšys, jog netinkama slaugytojų rankų higiena bei aseptika procedūrų metu, turi reikšmès dažnesniam intraveninių komplikacijų pasireiškimui. Tyrimo rezultatai parodè, jog venų punkciją sunkina sumažèjęs senyvų pacientų odos elastingumas $(r=0,301 ; p=0,005)$. Tyrimo rezultatai sutampa su anksčiau atliktais tyrimais $[4,10]$, kuriuose analizuo- 
jami intraveninių injekcijų atlikimo sunkumai dèl senyvų pacientų odos pakitimų: neelastinga, sumažėjęs poodinis riebalinis sluoksnis, suplonejusi, sausejjanti, raukšlèta ir kieta. Tyrimo duomenys parodè neigiamą ryši su teiginiu, kad intraveninès injekcijos vieta parenkama vadovaujantis nuojauta $(r=-0,333 ; p=0,002)$, nes $p<0,05$. Lyginant tyrimo rezultatus su kitais tyrimais [11], pastebimi sutapimai, jog intraveninès injekcijos vietą slaugytojai, turintys didesnę darbo patirtị nei 10 metuc, parenka vadovaudamiesi nuojauta, kuri pagrịsta analitiniu mąstymu, intuicija ir ankstesne patirtimi. Tai patvirtina koreliacija tarp darbo patirties ir amžiaus. Galime teigti, kad kuo darbo patirtis didesné, tuo labiau sutinkama su teiginiu, kad intraveninès injekcijos vieta parenkama vadovaujantis nuojauta, tuo labiau nesutinkama, kad paciento injekcijos paruošimas turi ịtakos komplikacijoms ir tuo labiau nesutinkama, kad paciento odos elastingumo sumažejimas dèl amžiaus sunkina venų punkciją. Aptikti pacientų skaičiaus per pamainą statistiškai reikšmingi neigiami ryšiai su teiginiais, kad periferinio venos kateterio laikymas ilgiau nei 48 val. ( $\mathrm{r}=-$ $0,248 ; p=0,024)$ ar 72 val. $(r=-0,233$; $\mathrm{p}=0,034)$ didina infekcijos ar venos uždegimo komplikacijų tikimybę. Šie tyrimo rezultatai sutampa su J. Pretz ir V. Folse aprašyto tyrimo rezultatais [11]. Intraveninès injekcijos vieta parenkama pagal sėkmingo pataikymo tikimybę $(r=-0,230 ; p=0,037)$. Lyginant su kitų tyrejų gautais rezultatais [5], išskiriama slaugytojų intuicija bei vadovavimasis analitiniu mąstymu intraveninių injekcijų atlikimo metu. Slaugytojai dažnai renkasi intraveninès injekcijos vietą savo nuožiūra (vena matoma ar čiuopiama), ar vadovaudamiesi individualia asmens anatomija. Analizuojant tyrimo rezultatus, aptiktas teigiamas ryšys su teiginiu, kad neadekvatus pacientų elgesys sunkina venų punkciją ( $\mathrm{r}=0,223 ; \mathrm{p}=0,042)$. Lyginant su kitais tyrimais [8], pastebima, jog intraveninių injekcijų atlikimą sunkino nenuspejjamas pacientų elgesys, injekci-

1 lentelė*. Intraveninių komplikacijų rizikos veiksnių ir darbo patirties, amžiaus, pacientų kiekio ir intraveninių injekcijų kiekio sąsajos, ${ }^{*} \mathrm{p}<0,05, * *<0,01$

*teiginiai pateikiami tik statistiškai reikšmingi.

\begin{tabular}{|c|c|c|c|c|c|}
\hline \multicolumn{2}{|l|}{ Teiginiai } & $\begin{array}{c}\text { Darbo } \\
\text { patirtis }\end{array}$ & Amžius & $\begin{array}{l}\text { Pacientų } \\
\text { skaičius }\end{array}$ & $\begin{array}{l}\text { Intraveninių in- } \\
\text { jekcijų skaičius }\end{array}$ \\
\hline \multirow{2}{*}{$\begin{array}{l}\text { Periferinio venos kateterio laikymas } \\
\text { ilgiau nei } 24 \text { val. didina komplikacijų } \\
\text { tikimybę }\end{array}$} & $\mathrm{r}$ & $-0,039$ & 0,002 & $-0,149$ & $-0,382^{* *}$ \\
\hline & $\mathrm{p}$ & 0,721 & 0,986 & 0,179 & 0,008 \\
\hline \multirow{2}{*}{$\begin{array}{l}\text { Periferinio venos kateterio laikymas } \\
\text { ilgiau nei } 48 \text { val. didina komplikacijų } \\
\text { tikimybę }\end{array}$} & $\mathrm{r}$ & $-0,156$ & $-0,019$ & $-0,248^{*}$ & $-0,215$ \\
\hline & $\mathrm{p}$ & 0,154 & 0,863 & 0,024 & 0,147 \\
\hline \multirow{2}{*}{$\begin{array}{l}\text { Periferinio venos kateterio laikymas } \\
\text { ilgiau nei } 72 \text { val. didina komplikacijų } \\
\text { tikimybę }\end{array}$} & $\mathrm{r}$ & 0,118 & 0,146 & $-0,233^{*}$ & 0,020 \\
\hline & $\mathrm{p}$ & 0,283 & 0,182 & 0,034 & 0,892 \\
\hline \multirow{2}{*}{$\begin{array}{l}\text { Parenterinè mityba didina komplika- } \\
\text { cijų tikimybę }\end{array}$} & $\mathrm{r}$ & 0,189 & 0,175 &,$- 272^{*}$ & $-0,015$ \\
\hline & $\mathrm{p}$ & 0,084 & 0,110 & 0,013 & 0,919 \\
\hline \multirow{2}{*}{$\begin{array}{l}\text { Venų pradūrimas ịvyksta dažniau } \\
\text { naktį nei dieną }\end{array}$} & $\mathrm{r}$ & 0,104 & 0,119 & $-0,129$ & $-0,374^{* *}$ \\
\hline & $\mathrm{p}$ & 0,344 & 0,279 & 0,245 & 0,010 \\
\hline \multirow{2}{*}{$\begin{array}{l}\text { Intraveninès injekcijos vieta paren- } \\
\text { kama vadovaujantis nuojauta }\end{array}$} & $\mathrm{r}$ & $-0,333^{* *}$ & $-0,266^{*}$ & 0,046 & $-0,179$ \\
\hline & $\mathrm{p}$ & 0,002 & 0,014 & 0,681 & 0,229 \\
\hline \multirow{2}{*}{$\begin{array}{l}\text { Intraveninès injekcijos vieta paren- } \\
\text { kama pagal tikimybę sékmingiau } \\
\text { pataikyti }\end{array}$} & $\mathrm{r}$ & $-0,068$ & $-0,012$ & $-0,230^{*}$ & $-0,130$ \\
\hline & $\mathrm{p}$ & 0,534 & 0,913 & 0,037 & 0,384 \\
\hline \multirow{2}{*}{$\begin{array}{l}\text { Paciento punkcijos vietos tinkamas } \\
\text { aseptinis paruošimas turi įtakos intra- } \\
\text { veninių injekcijų komplikacijų rizikai }\end{array}$} & $\mathrm{r}$ & $0,217^{*}$ & 0,196 & $-0,097$ & 0,096 \\
\hline & $\mathrm{p}$ & 0,047 & 0,073 & 0,381 & 0,520 \\
\hline \multirow{2}{*}{$\begin{array}{l}\text { Paciento odos elastingumo sumažejji- } \\
\text { mas pagyvenusiame amžiuje sunkina } \\
\text { venų punkciją }\end{array}$} & $\mathrm{r}$ & $0,301^{* *}$ & $0,282^{* *}$ & $-0,176$ & $-0,247$ \\
\hline & $\mathrm{p}$ & 0,005 & 0,009 & 0,111 & 0,094 \\
\hline \multirow{2}{*}{$\begin{array}{l}\text { Neadekvatus pacientų elgesys sunkina } \\
\text { venų punkciją }\end{array}$} & $\mathrm{r}$ & 0,137 & 0,096 & $0,223^{*}$ & $-0,016$ \\
\hline & $\mathrm{p}$ & 0,211 & 0,384 & 0,042 & 0,913 \\
\hline
\end{tabular}

2 lentelè. Intraveninių komplikacijų dažnumo ir darbo patirties, amžiaus, pacientų kiekio ir intraveninių injekcijų kiekio sąsajos, ${ }^{*} \mathrm{p}<0,05, * *<0,01$

\begin{tabular}{|c|c|c|c|c|c|}
\hline \multicolumn{2}{|l|}{ Teiginiai } & $\begin{array}{c}\text { Darbo } \\
\text { patirtis }\end{array}$ & Amžius & $\begin{array}{l}\text { Pacientų } \\
\text { skaičius }\end{array}$ & $\begin{array}{l}\text { Intraveniniụ in- } \\
\text { jekcijų skaičius }\end{array}$ \\
\hline \multirow{2}{*}{$\begin{array}{l}\text { Kraujavimas, hematoma dažnai } \\
\text { ivyksta periferinio kateterio ịvedimo } \\
\text { metu }\end{array}$} & $\mathrm{r}$ & $0,221^{*}$ & 0,209 & 0,001 & $-0,029$ \\
\hline & $\mathrm{p}$ & 0,042 & 0,055 & 0,993 & 0,846 \\
\hline \multirow{2}{*}{$\begin{array}{l}\text { Oro embolija dažnai ịvyksta periferi- } \\
\text { nio kateterio įvedimo metu }\end{array}$} & $\mathrm{r}$ & $-0,013$ & 0,031 & $-0,194$ & $-0,350^{*}$ \\
\hline & $\mathrm{p}$ & 0,907 & 0,776 & 0,079 & 0,016 \\
\hline \multirow{2}{*}{$\begin{array}{l}\text { Dažnai ịvyksta kateterio okliuzija } \\
\text { (užkrešèjimas) }\end{array}$} & $\mathrm{r}$ & 0,152 & 0,116 & $-0,108$ & $-0,167$ \\
\hline & $\mathrm{p}$ & 0,165 & 0,290 & 0,331 & 0,263 \\
\hline \multirow{2}{*}{$\begin{array}{l}\text { Dažnai ịvyksta kateterio ịvedimo vie- } \\
\text { tos infekcija }\end{array}$} & $\mathrm{r}$ & 0,109 & 0,159 & $-0,097$ & $-0,373^{* *}$ \\
\hline & $\mathrm{p}$ & 0,323 & 0,146 & 0,382 & 0,010 \\
\hline \multirow{2}{*}{$\begin{array}{l}\text { Flebitas dažnai ịvyksta po periferinio } \\
\text { kateterio įvedimo }\end{array}$} & $\mathrm{r}$ & 0,019 & 0,113 & $-0,097$ & $-0,126$ \\
\hline & $\mathrm{p}$ & 0,866 & 0,305 & 0,381 & 0,398 \\
\hline \multirow{2}{*}{$\begin{array}{l}\text { Sepsis dažnai įvyksta po periferinio } \\
\text { kateterio įvedimo }\end{array}$} & $\mathrm{r}$ & $-0,160$ & $-0,146$ & $-0,122$ & $-0,404^{* *}$ \\
\hline & $\mathrm{p}$ & 0,143 & 0,181 & 0,272 & 0,005 \\
\hline \multirow{2}{*}{$\begin{array}{l}\text { Venos trombozè dažnai ịvyksta po } \\
\text { centrinio kateterio įvedimo }\end{array}$} & $\mathrm{r}$ & 0,114 & 0,086 & $-0,097$ & $-0,357^{*}$ \\
\hline & $\mathrm{p}$ & 0,300 & 0,436 & 0,385 & 0,014 \\
\hline
\end{tabular}


jos metu keliantis pavojų pacientui ir intraveninę injekciją atliekančiam slaugytojui. Dèl to ilgejja procedūros laikas, didesnè intraveninių komplikacijų tikimybè. Tyrimo duomenys parodè, kad kuo didesnis pacientų skaičius per pamainą, tuo labiau sutinkama, kad periferinio venos kateterio laikymas ilgiau nei 48 ar 72 val. didina komplikacijų tikimybę; tuo labiau sutinkama, kad intraveninès injekcijos vieta parenkama pagal tikimybę sèkmingiau pataikyti; tuo labiau nesutinkama, kad neadekvatus pacientų elgesys sunkina venų punkciją. Aptikti intraveninių injekcijų skaičiaus per pamainą statistiškai reikšmingi neigiami ryšiai su teiginiais, kad periferinio venos kateterio laikymas ilgiau nei 24 val. didina komplikacijų tikimybę $(\mathrm{r}=0,382 ; \mathrm{p}=0,008)$ ir venos dažniau praduriamos naktic, nei dieną $(r=0,374 ; \mathrm{p}=0,010)$. Galime teigti, kad kuo intraveninių injekcijų skaičius per pamainą didesnis, tuo labiau sutinkama, kad periferinio venos kateterio laikymas ilgiau nei 24 val. didina komplikacijų skaičių ir tuo labiau sutinkama, kad venos dažniau praduriamos naktị nei dieną. Tyrimo rezultatai parodè statistiškai reikšmingą teigiamą ryši tarp darbo krūvio ir teiginio, kad kuo didesnis darbo krūvis pamainos metu, tuo dažnesnès intraveninès komplikacijos $(\mathrm{r}=0,287 ; \mathrm{p}=0,029)$ slaugytojams, turintiems iki 5 metų darbo patirties ir su teiginiu, kad kuo didesnis darbo krūvis, tuo labiau nesutinkama, kad dèl to ịvyksta daugiau komplikacijų, slaugytojams, turintiems daugiau nei 20 metų darbo patirties.

Tyrimo metu analizuotas intraveninių komplikacijų dažnumas. Dauguma slaugytojų sutiko su teiginiais, kad dažnai ìvyksta kateterio okliuzija $(2,53 \pm 1,06)$, kraujavimas, hematoma dažna periferinio kateterio įvedimo metu $(2,58 \pm 0,99)$ ir flebitas dažnai prasideda po periferinio kateterio įvedimo $(3,06 \pm 0,96)$. Slaugytojai nesutiko su teiginiais, kad sepsis dažnai ịvyksta po periferinio kateterio įvedimo $(3,82 \pm 0,89)$, oro embolija dažna periferinio kateterio ịvedimo metu $(3,73 \pm 0,97)$, venos trombozè dažnai ịvyksta po centrinio kateterio ịvedimo $(3,38 \pm 0,83)$ (5 pav.) Lyginant pagal slaugytojų darbo patirtį, statistiškai reikšmingų skirtumų neaptikta.

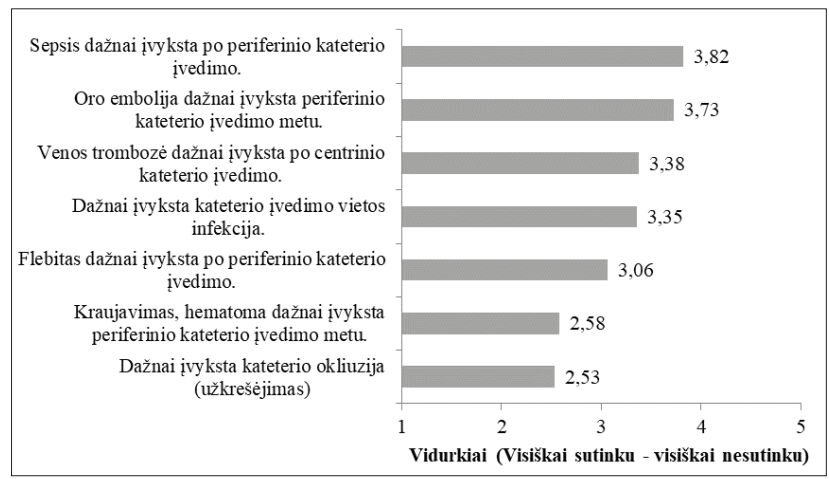

5 pav. Intraveninių komplikacijų dažnumas, vidurkiai
Analizuojant intraveninių komplikacijų dažnumo ir darbo patirties sąsajas, atlikta koreliacinè (Spearman) analizė (2 lentelè). Tyrimo rezultatai parodè statistiškai reikšmingus teigiamus darbo patirties ryšius su teiginiu, kad kraujavimas, hematoma dažnai ịvyksta periferinio kateterio ịvedimo metu $(\mathrm{r}=0,221 ; \mathrm{p}=0,042)$. Galime teigti, kad kuo didesnè slaugytojų darbo patirtis, tuo labiau nesutinkama, kad kraujavimas dažnai įvyksta periferinio kateterio įvedimo metu. Atliktų tyrimų rezultatai parode, jog pradedantiesiems slaugytojams šios komplikacijos pasitaiko dvigubai dažniau dèl praktinio darbo patirties stokos [5]. Aptikti intraveninių injekciju skaičiaus per pamainą statistiškai reikšmingi neigiami ryšiai su teiginiais, kad oro embolija dažnai ịvyksta periferinio kateterio ịvedimo metu $(\mathrm{r}=-0,350 ; \mathrm{p}=0,016)$, dažna kateterio ivedimo vietos infekcija $(r=-0,373 ; p=0,010)$, sepsis dažnai ivvyksta po periferinio kateterio ịvedimo $(\mathrm{r}=-0,404 ; \mathrm{p}=0,005)$, o venos tromboze - po centrinio kateterio ịvedimo $(r=-0,357$; $\mathrm{p}=0,014)$. Galime teigti, kad kuo didesnis atliekamų intraveninių injekcijų skaičius per pamainą, tuo labiau sutinkama su įvardytais teiginiais.

\section{Išvados}

1. Intraveninių komplikacijų pagrindiniai rizikos veiksniai: higienos, aseptikos ir antiseptikos taisyklių bei intraveninio kateterio naudojimo metodikos netinkamas laikymasis ir mikroorganizmų patekimas ant išorinio ar vidinio intraveninio kateterio paviršiaus jo įvedimo metu. Rizikingas kateterizavimo laikotarpis, jeigu laiku nepakeičiamas ar per ilgai nepašalinamas intraveninis kateteris. Slaugytojo kritiškai neįvertinta paciento gyvybei pavojinga būkle gali kelti intraveninių injekcijų komplikacijų riziką.

2. Tyrimo metu nustatyta, kad didesnę darbo patirtị turintys slaugytojai, susidūrę su kritinėmis situacijomis, gausiu pacientų skaičiumi ir dideliu darbo krūviu, atliekantys daug intraveninių injekcijų, igauna vertingų praktinių igūdžių, reikalingų gerinti slaugos paslaugų kokybę. Slaugytojai, turintys didesnę nei 10 metų darbo patirti, atlikdami intravenines injekcijas, vadovaujasi analitiniu ir kritiniu mąstymu, nuojauta. Ivertina pacientų kontraindikacijas, taip mažindami komplikacijų riziką. Pradedantiesiems slaugytojams sudètingiau atlikti intravenines injekcijas kritinèse situacijose, vertinti paciento būklę ir galimas intravenines komplikacijas, jie vadovaujasi tik venų čiuopimu ir matomumu. Intraveninių komplikacijų riziką didina nuovargis, įtampa bei darbo specifika.

\section{Literatūra}

1. Dreesen M, Foulon V, Spriet I, Goossens GA, Hiele M, De Poucq L, Willems L. Epidemiology of catheter-related infections in adult patients receiving home parenteral nutrition: a systematic 
review. Clin Nutr 2013;32(1):16-26.

https://doi.org/10.1016/j.clnu.2012.08.004

2. Dychter SS, Gold DA, Carson D, Haller M. Intravenous therapy: a review of complications and economic considerations of peripheral access. Journal of Infusion Nursing 2012;35(2):84-91. https://doi.org/10.1097/NAN.0b013e31824237ce

3. Fram D, Okuno M, Taminato M, Ponzio V, Manfredi S, Grothe C, Belasco A, Sesso R, Barbosa D. Risk factors for blood stream infection in patients at a Brazilian haemodialysis centre: a case - control study. BMC Infectious Diseases 2015;15:158. https://doi.org/10.1186/s12879-015-0907-y

4. Kaye KS, Marchaim D, Chen T, Chopra T, Anderson DJ, Choi Y, Sloane R, Schamader KE. Predictors of nosocomial bloodstream infections in older adults. Journal of the American Geriatrics society 2011; 59(4):622-627. https://doi.org/10.1111/j.1532-5415.2010.03289.x

5. Labeau SO, Vandijck DM, Rello J, Adam S, Rosa A, Wenisch C, Bäckman C, et al. Centers for Disease Control and Prevention guidelines for preventing central venous catheter-related infection: results of a knowledge test among 3405 European intensive care nurses. Critical Care Medicine 2009;37(1):320-323. https://doi.org/10.1097/CCM.0b013e3181926489

6. Martínez-Morel H, Sánchez-Payá J, Molina-Gómez M, GarcíaShimizu P, García Román V, Villanueva-Ruiz C, GonzálezHernández M, Nolasco-Bonmatí A. Catheter related blood stream infection: burden of disease in a tertiary hospital. Journal of Hospital Infection 2014;87:165-170.

https://doi.org/10.1016/j.jhin.2014.04.008

7. Mattox EA. Complications of peripheral venous access devices: prevention, detection, and recovery strategies. Critical Care Nurse 2017;37(2):14. https://doi.org/10.4037/ccn2017657

8. Merlin MA, Saybolt M, Kapitanyan R, Alter SM, Jeges J, Liu J, et al. Intranasal naloxone delivery is an alternative to intravenous naloxone for opioid overdoses. Am J Emerg Med 2010; 28(3):296-303. https://doi.org/10.1016/j.ajem.2008.12.009

9. Morrison K, Holt KE. The effectiveness of clinically indicated replacement of peripheral intravenous catheters: an evidence review with implications for clinical practice. Worldviews Evid Based Nurs 2015;12(4):187-198. https://doi.org/10.1111/wvn.12102

10. Murea M, James KM, Russel GB, Byrum GV, Yates JE, Tuttle NS, Bleyer AJ, Burkart JM, Freedman BI. Risk of catheter-rela- ted bloodstream infection in elderly patients on haemodialysis. Clin J Am Soc Nephrol 2014;9(4):764-770.

https://doi.org/10.2215/CJN.07710713

11. Pretz JE, Folse VN. Nursing experience and preference for intuition in decision making. J Clin Nurs 2011;20(19-20):28782889.

https://doi.org/10.1111/j.1365-2702.2011.03705.x

\section{THE LINKS BETWEEN THE WORK EXPERIENCE OF NURSES AND COMPLICATIONS OF INTRAVENOUS INJECTIONS}

D. Narvilienė, J. Vaitiekienė, L. Visockytė

Keywords: intravenous injections, injection complications, work experience of nurses.

Summary

The aim of the study was to analyze the links between the work experience of nurses and complications of intravenous injections. An anonymous written survey was conducted, during which 185 nurses working in various health care profiles were interviewed. The data were statistically processed by SSPS 23.0 statistical software package. Frequency and means analysis of quantitative variables were performed. The frequency (n) of the study data, its percentage (percent), mean and standard deviation were calculated. The Mann - Whitney test was used for the comparison between two independent variables. The Spearman correlation coefficient $(\mathrm{r})$ and its significance $(\mathrm{p})$ were used to determine the relationships. The statistical significance of the hypotheses was confirmed when $p \leq 0.05$. The study showed that nurses with many years of work experience, more than 10 years, had fewer complications with intravenous injections than nurses with less experience. The results of the study showed that nurses working in one field for at least 20 years use intuition and analytical and critical decision-making. It is more difficult to perform intravenous injections in critical situations, to assess the patient's condition and possible complications of intravenous injections for nurses with work experience of up to five years. The results of this study helped to establish the association of intravenous injection complications with the work experience of nurses in order to avoid or at least reduce the complications caused. The experience of nurses is important in the decision-making process because the experience factor is the qualitative difference between a novice and a more experienced nurse.

Correspondence to: j.vaitiekiene@kul.lt

Gauta 2020-11-26 